\title{
ODONTOLOGŲ, AKUŠERIŲ IR NĖŠČIUUJŲ SUVOKIMO BEI ŽINIŲ APIE BURNOS LIGŲ GYDYMĄ BEI PROFILAKTIKĄ NĖŠTUMO METU IVERTINIMAS KAUNO MIESTE
}

\author{
Eglė Aida Bendoraitiené ${ }^{1}$, Aistė Marcinkevičiūtė ${ }^{2}$, Mindaugas Gutpetris ${ }^{2}$ \\ ${ }^{1}$ Lietuvos sveikatos mokslu universiteto Burnos priežiūros ir vaiku odontologijos klinika, \\ ${ }^{2}$ Lietuvos sveikatos moksly universitetas
}

\author{
Raktažodžiai: nėštumas, burnos sveikata, prenatalinė \\ priežiūra.
}

\section{Santrauka}

Tyrimo tikslas. Ivertinti ir palyginti odontologų, akušerių, néščiųų žinias bei požiūrị i burnos ligų gydymą bei profilaktiką, jų būtinumą, prieinamumą ir saugumą něštumo metu. Metodika. Atlikta anoniminè vienmomentė anketinè apklausa Kauno viešosiose medicinos įstaigose, kurioje dalyvavo 41 odontologas, 53 akušerès ir 341 něščioji. Rezultatai. Dauguma akušerių lyginant su odontologais prastą burnos būklę sieja su nepalankia nèštumo baigtimi. Odontologai prasčiau vertina nėščiujų žinias ir supratimą apie dantų priežiūros svarbą lyginant su akušeriais $(p<0,05)$. Nors 88 proc. moterų nurodè, kad vizitai pas odontologą nèštumo metu yra saugūs, tačiau tik 68,3 proc. nëščiujų apsilankè. 83 proc. odontologų ir 75,5 proc. akušerių nebendradarbiauja tarpusavyje. 79,8 proc. něščiujų, kurioms gydytojai rekomendavo, apsilankè pas odontologą $(\mathrm{p}<0,001)$. Išvados. Néštumo metu atsiranda didesnė rizika burnos patologijai išsivystyti, kuri gali nulemti nėštumo baigti. Dauguma néščiujų lankėsi pas odontologą ir mano, jog vizitai yra saugūs. Gydytojų rekomendacijos apsilankyti pas odontologus turi ịtakos nėščiujų apsisprendimui.

\section{Ivadas}

Nèštumas yra ypatinga būklè, kurios metu tiek moteris, tiek besiformuojantis vaisius susiduria su ịvairiais rizikos faktoriais, galinčiais paveikti jų sveikatą. Dẻl šios priežasties išskirtinis dèmesys turi būti skiriamas néščiųjų ligų prevencijai ir profilaktikai, siekiant užtikrinti palankią sveikatos būklę bei gyvenimo kokybę. Teigiama, jog prasta motinos burnos sveikata gali paveikti néštumą ir prisidèti prie mažo svorio kūdikių gimimo, priešlaikinio gimdymo bei turèti įtakos išsivystyti ankstyvajam vaikų dantų èduoniui $[1,2]$.

Lietuvoje žinios apie burnos priežiūrą, vykdomas prevencines programas yra nepakankamos ir priklauso nuo gyventojų išsilavinimo ir gaunamų pajamų [3]. Šiuo atveju něštumo metu visos moterys (nepriklausomai nuo jų išsilavinimo, gaunamų pajamų) linkusios lankytis pas ginekologus ir akušerius dažniau nei pas kitus sveikatos priežiūros specialistus, todèl minèti gydytojai turi lemiamą vaidmeni užtikrinant moterų sveikatą. Teigiama, jog ginekologines ir akušerines paslaugas teikiantys specialistai yra palankioje strategineje padètyje teikiant informaciją apie burnos sveikatos svarbą ir rekomenduojant apsilankyti pas odontologus něščioms moterims [4].

Remiantis tyrimų duomenimis, nëščios moterys 3 kartus dažniau susiduria su dantų ėduonimi ir 2 kartus dažniau su periodonto ligomis [5]. Dauguma akušerių ir ginekologų pritaria nuomonei, jog visos besilaukiančios moterys turètų apsilankyti pas odontologą [6]. O gydytojai vizito metu turètų aptarti burnos priežiūros reikšmę, ịtaką néštumui ir esant indikacijoms paskirti atitinkamą gydymą. Tačiau, kita vertus, prenatalinis laikotarpis yra vienas jautriausių periodų žalingiems aplinkos veiksniams. Todèl tiek néščiosios, tiek akušeriai bei gydytojai odontologai skeptiškai žiūri i dantų gydymą bei ne visada užtikrinti atliekamų procedūrų saugumu $[7,8]$.

Šio straipsnio tikslas - palyginti odontologų, akušerių ir néščiujų žinias bei požiūrị i burnos ligų gydymą bei profilaktiką, jų būtinumą, prieinamumą ir saugumą nėštumo metu.

\section{Metodika}

Tyrimui atlikti buvo gautas Lietuvos sveikatos mokslų universiteto Bioetikos centro leidimas (Nr.BEC - OF - 870). Anoniminè vienmomentè anketinè apklausa vyk- 
dyta 201507 - 2015 10, kurioje dalyvavo 41 odontologas, 53 akušerès ir 341 néččioji. Néščiujų grupès imties dydis apskaičiuotas remiantis Lietuvos statistikos departamento 2014 m. leidinio duomenimis pagal 2013m. Kauno miesto savivaldybejje gyvų gimusių kūdikių skaičiu (3032) [9]. Nëščiosioms išdalintos 420 anketų, gauta 341 atsakyta anketa (atsako dažnis - 81 proc.) Kadangi Lietuvoje nèra statistinių duomenų, nurodančių akušerių ir odontologų skaičių (dirbančiu viešosiose ịstaigose) Kauno mieste, buvo siekiama apklausti kiekvieną tiriamajji. Sveikatos priežiūros specialistams išplatinus 110 anketų, gautos 94 atsakytos anketos (atsako dažnis - 85 proc.)

Tyrimas buvo atliekamas viešosiose Kauno miesto medicinos istaigose, kuriose apklaustas kiekvienas tiriamos grupès respondentas, sutikęs dalyvauti tyrime. Bendrosios praktikos odontologai buvo apklausiami 5 Kauno miesto poliklinikose, o akušerès (dirbančios moterų konsultacijų skyriuose bei stacionaruose) ir néščiosios buvo apklausiamos klinikose, teikiančiose stacionarines paslaugas Kaune.

Tyrimui atlikti sudaryti trys klausimynai. Odontologai ir akušeriai buvo apklausiami panašiais, ir jei tik įmanoma, identiškais klausimais. Akušerių anketa parengta iš 12 ,

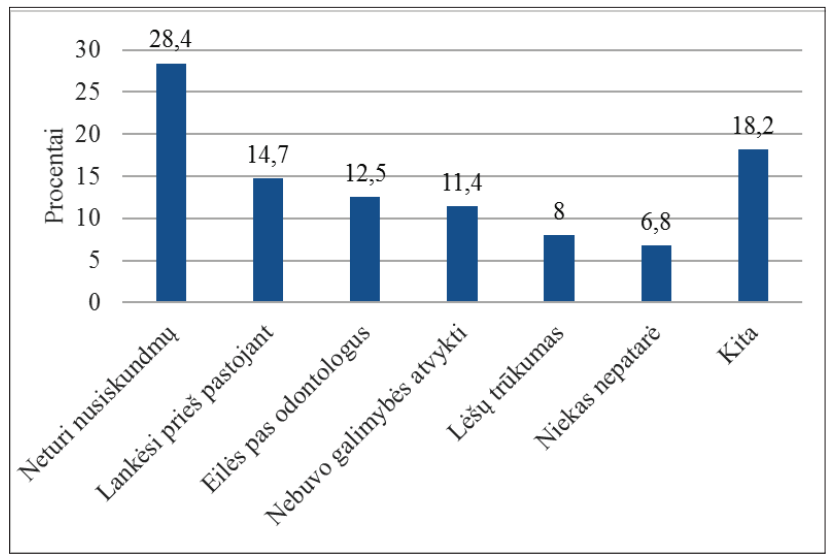

1 pav. Priežastys, dèl kurių pacientės nebuvo apsilankiusios pas odontologą nèštumo metu

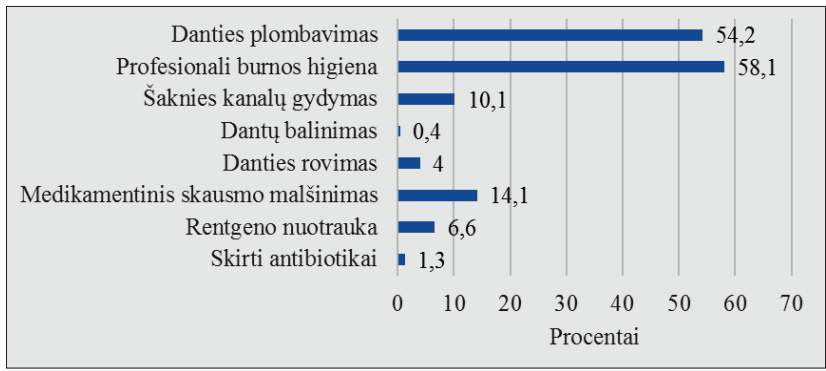

2 pav. Nèštumo metu atliktos odontologinès procedūros odontologų iš 10 , něščiųjų iš 15 klausimų, siekiant ịvertinti respondentų žinias bei požiūrị ị burnos ligų gydymą bei profilaktiką néštumo metu.

Statistinè gautų duomenų analizè atlikta naudojant statistinị duomenų analizès paketą IBM SPSS Statistics 23.0. Kiekybinio požymio, tenkinančio normalinio skirstinio sąlygas, reikšmių vidurkiai tiriamosiose dviejose nepriklausomose grupėse lyginti taikant parametrini Stjudent'o $\mathrm{t}$ kriterijų nepriklausomoms populiacijoms. Kokybinių požymių priklausomybei nustatyti lyginamosiose grupése vertintas chi kvadrato kriterijus. Stebèti skirtumai bei priklausomybės tarp požymių buvo laikyti statistiškai reikšmingais, kai reikšmingumo lygmuo $\mathrm{p}<0,05$.

\section{Rezultatai}

68,3 proc. moterų lankèsi pas odontologą nèštumo metu; 31,7 proc. néščiujų nebuvo atlikta odontologiné apžiūra, gydymo intervencijos. Priežastys, kodèl besilaukiančios moterys nebuvo apsilankiusios pas odontologą, nurodytos 1 pav.

Nėščiujų, kurios lankèsi pas odontologą, buvo pasiteirauta apie atliktas procedūras. Daugiau nei pusei respondenčiu buvo atliktas dantų plombavimas bei profesionali burnos higiena. Kitos odontologinès procedūros buvo atliekamos kiek rečiau. Mažiausiai moterų daliai buvo atliktas dantų balinimas ir skirti antibiotikai. Nèštumo metu atliktų odontologinių procedūrų pasiskirstymas pateikiamas 2 pav.

65,4 proc. besilaukiančių pacienčių mano, jog apsilankymai pas odontologus néštumo metu yra svarbesni, nei nesant néščiai. 32,8 proc. teigia, jog vizitai pas odontologus yra vienodai svarbūs visais laikotarpiais.

88 proc. moteru nurodè, kad lankytis pas odontologą néštumo metu yra saugu. Likusi dalis besilaukiančių pacienčių (9,4 proc.) mano priešingai. Dauguma néščiujų (40 proc.) nurodè, kad lankytis pas odontologą néštumo metu yra nesaugu dèl naudojamų anestetikų, medikamentų procedūrų metu. 33,3 proc. néščiujų ịvardijo, jog joms kelia nerimą kraujo užkrètimo, infekcijų pavojaus galimybė; 30 proc. - konkrečios odontologinès procedūros (profesionali burnos higiena, rentgenologinis ištyrimas, danties rovimas); 16,6 proc. - patiriamas stresas, baimé, skausmas.

Didesne dalis akušerių, lyginant su odontologais, prastą burnos būklę sieja su nepalankia néštumo baigtimi. Tuo tarpu didesnè dalis odontologų mano, jog nèra jokių asociacijų tarp burnos būklès ir nèštumo baigties (3 pav.).

I klausimą, kuriame/kuriuose néštumo trimestruose gali būti atliekama odontologinè apžiūra, daugiau nei pusė apklaustujų atsake, jog bet kuriame laikotarpyje (67,9 proc. akušerių; 73,2 proc. odontologų). 20,8 proc. akušerių ir 2,4 proc. odontologų teigia, kad odontologinè apžiūra gali būti atliekama pirmajame néštumo trimestre $(\mathrm{p}<0,01), 15,1$ 


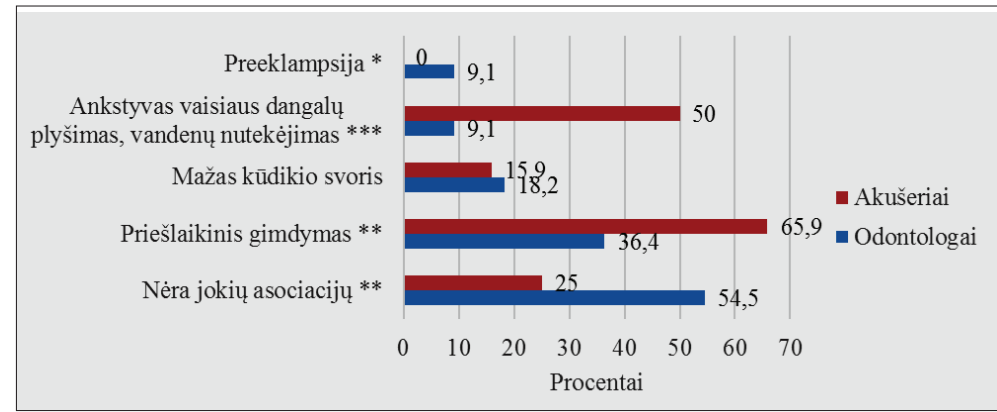

3 pav. Prastos burnos būklès įtaka nèštumui $\left({ }^{*} p<0,05, *^{*} p<0,01, *^{* * *}<<0,001\right)$

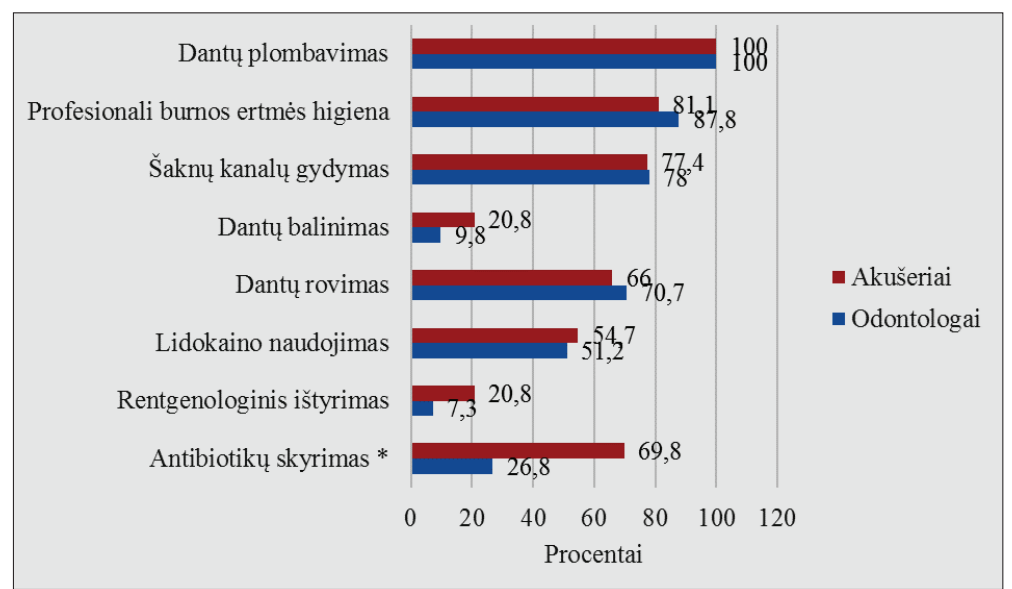

4 pav. Procedūros, kurios gali būti atliekamos moterims nėštumo metu $\left({ }^{*} p<0,001\right)$

proc. akušerių ir 19,5 proc. odontologų- antrajame trimestre, 1,9 proc. akušerių ir 12,2 proc. odontologų - trečiajame trimestre $(\mathrm{p}<0,05)$.

Sveikatos priežiūros specialistai panašiai vertina daugumą procedūrų, kurios gali būti atliekamos néščiosioms. Tačiau labiausiai tiriamujjų grupių nuomonès išsiskiria antibiotikų skyrimo klausimu (4 pav.).

Odontologai prasčiau vertina něščiujų žinias ir supratimą apie dantų priežiūros svarbą lyginant su akušeriais. 42,5 proc. odontologų ir 16 proc. akušerių besilaukiančių pacienčių žinias vertina prastai. Didžioji dalis odontologų (55 proc.) ir akušerių ( 80 proc.) něščiju žinias vertina gerai, likusieji - labai gerai. Nustatytas statistiškai reikšmingas skirtumas tarp odontologų ir akušerių respondentų grupių, vertinant nèščiųjų žinias ir supratimą apie dantų priežiūros svarbą $(\mathrm{p}<0,05)$.

Dauguma akušeriu (94,3 proc.) ir odontologų (97,6 proc.) mano, kad kiekvienai nėščiajai turètų būti atliekama burnos patikra kaip dalis něščiujų priežiūros. Tačiau net 83 proc. akušerių ir 75,5 proc. odontologų nebendradarbiauja su sveikatos priežiūros specialistais nèščiujų burnos priežiūros klausimais. Ir tik 41,5 proc. akušerių rekomenduoja něščiosioms kreiptis pas odontologą.

Gydytojų rekomendacijos apsilankyti pas odontologus turèjo įtakos něščiujų apsisprendimui. Net 79,8 proc. pacienčių, kurioms gydytojai rekomendavo, apsilankè pas odontologą. Tuo tarpu 57,4 proc. néščiujų, kurioms gydytojai nepatarè, nesilankè pas odontologą. Nustatytas statistiškai reikšmingas skirtumas tarp gydytojų rekomendacijų apsilankyti pas odontologą ir néščiųjų apsilankymo $(\mathrm{p}<0,001)$.

Néščiujų buvo klausiama, kokie sveikatos priežiūros specialistai joms patare apsilankyti pas odontologą. Dauguma respondenčių (77,5 proc.) nurode, kad joms apsilankyti pas odontologą rekomendavo gydytojas akušeris - ginekologas. 21,4 proc. nëščiujų atsakè, kad rekomendavo šeimos gydytojas. Likusi dalis pacienčių ( 1,1 proc.) pasirinko „kita“ atsakymo variantą (ir ịrašè - akušeris).

\section{Rezultatu aptarimas}

Apsilankymai pas odontologą nèštumo metu svarbūs net ir tuomet, kai pacientès neišsako konkrečių nusiskundimų. Remiantis atlikto tyrimo rezultatais, didesne dalis moteru mano, jog apsilankymai pas burnos sveikatos priežiūros specialistą něštumo metu yra svarbesni nei nesant néščiai. 68,3 proc. tyrime dalyvavusių respondenčių lankèsi pas odontologą nèštumo metu. Tuo tarpu $2011 \mathrm{~m}$. Vilniuje atlikto tyrimo rezultatai atskleidžia, kad pas odontologą buvo apsilankiusios net 83,5 proc. besilaukiančių moterų [10]. Analizuojant Prancūzijoje atlikto tyrimo duomenis, nustatyta, kad 57 proc. moterų néštumo metu susidūrè su bent viena odontogeninès kilmès problema, kai 20 proc. patyré dantų skausmą [11]. Teigiama, jog 56 proc. moterų nesilanké pas odontologą nèštumo metu, 26 proc. moterų konsultavosi su odontologu dèl odontologinès kilmès problemos ir tik 18 proc. moteru apsilankè pas odontologą profilaktiniam patikrinimui nëštumo metu [11]. Lyginant šiuos duomenis, galima teigti, jog Lietuvoje moterys labiau linkusios apsilankyti pas odontologą.

Dauguma moterų, kurioms nebuvo atlikta odontologinè apžiūra, gydymo intervencijos něštumo metu, nesilankè pas odontologą, kadangi neturejjo jokių nusiskundimų (28,7 proc.). Tuo tarpu Amerikoje pagrindinè priežastis buvo susijusi su finansinių išteklių trūkumu [12]. Šis rezultatas leidžia patvirtinti ankstesnių tyrimų gautas išvadas, jog Lietuvoje dažniausios atvykimo pas gydytoją odontologą priežastys nurodomos dantų ligos ir skausmas [13]. 
Moksliniuose leidiniuose yra įvairių nuomonių dèl burnos ertmès ligų ịtakos néštumui, tačiau šiuo metu pasaulyje vis labiau daugèja tyrimų, kurie nurodo, jog periodonto ligų aktyvumas néštumo metu gali prisidèti prie mažo svorio kūdikių gimimo, priešlaikinio gimdymo, ankstyvo vaisiaus dangalų plyšimo, preeklampsijos išsivystymo ir taip nulemti néštumo baigti [1]. Remiantis atlikto tyrimo duomenimis, dauguma akušerių, lyginant su odontologais, prastą burnos būklę sieja su nepalankia nèštumo baigtimi. Tuo tarpu daugiau nei pusę apklaustų odontologų (54,5 proc.) mano, jog nèra jokių asociacijų tarp burnos būklès ir nèštumo baigties. Panaši nuomone stebima ir kitose šalyse, pavyzdžiui, Amerikoje atlikto tyrimo metu akušeriai buvo labiau linkę sieti prastą burnos sveikatą su priešlaikiniu gimdymu, mažo svorio kūdikių gimimu, ankstyvu vaisiaus dangalų plyšimu [12]. Tačiau odontologai, labiau nei akušeriai, mano, jog nèštumas didina periodonto patologijos atsiradimo riziką ir ligos progresavimą. Kita vertus, remiantis literatūros duomenimis, pats nëštumas nesukelia periodonto ligų, o pablogina jau esamą būklę [14].

Teigiama, jog burnos ligų prevencija, diagnostika ir gydymas, iskaitant medikamentų naudojimą, yra saugus ir gali būti atliekamas néštumo metu be papildomos rizikos motinai ir vaisiui, lyginant su atsirandančia rizika neteikiant pagalbos [15]. Didžioji dalis tyrime dalyvavusių odontologų ir akušerių nurodè, kad odontologinè apžiūra gali būti atliekama bet kuriame nèštumo trimestre. Remiantis Amerikos vaikų odontologų akademijos rekomendacijomis, visos besilaukiančios moterys turètų apsilankyti pas odontologą per pirmaji nèštumo trimestrą. Šiuo metu atliekamas paciento ištyrimas ir taikomos profilaktinès programos. Gydomosios procedūros atliekamos antrajame trimestre. Jeigu individuali burnos priežiūra nepakankama, profilaktinès odontologinès procedūros gali būti atliekamos ir trečiajame trimestre [16].

Literatūroje teigiama, jog néštumas nėra liga ir néščios moterys neturètų būti gydomos kitaip nei visa likusi populiacija, bet būna ir prieštaringų situacijų. Daugelis tyrime dalyvavusių respondenčių (88 proc.) nurodè, kad lankytis pas odontologą néštumo metu yra saugu. Likusiai daliai moterų didžiausią nerimą kèlè naudojamų medikamentų saugumas. Taip pat apklausus odontologus ir akušerius, nuomonès statistiškai reikšmingai išsiskyrè antibiotikų skyrimo klausimu. O Amerikoje atlikto tyrimo metu tiek odontologai, tiek akušeriai nurodè, kad burnos sveikatos priežiūros specialistai ne visada jaučiasi užtikrintai dirbdami su nėščiosiomis dèl nerimo, jog odontologinès procedūros gali būti nesaugios besilaukiančioms pacientèms [12]. Šiuos rezultatus būtų galima aiškinti tuo, kad ligi šiol trūksta konkrečių, patikimų nuorodų bei logoritmų, kaip konkrečiomis situacijomis reikètų pasielgti gydytojams tei- kiant pagalbą néččiosioms. Tačiau medikamentai nėštumo metu privalo būti skiriami tuomet, kai jie yra būtini siekiant užtikrinti gerą néščiosios savijautą ir būklę, kadangi išplitus infekcijai atsiranda žymiai didesnè grèsmé tiek motinai, tiek vaisiui.

Siekiant užtikrinti visapusišką sveikatos priežiūros poreikių patenkinimą, reikalingas komandinis gydytojų darbas. Remiantis $2013 \mathrm{~m}$. Amerikoje atlikto tyrimo rezultatais, pacientai, kuriems akušeriai patare apsilankyti pas odontologą ir informavo apie geros burnos sveikatos svarbą, buvo šešis kartus labiau linkę daugiau dèmesio skirti savo burnos sveikatai. Taip pat keturis kartus labiau tiketina, kad šie pacientai apsilankè ar planuoja apsilankyti pas odontologą [17]. Tačiau galima teigti, jog tiek Amerikoje, tiek Europoje bendradarbiavimas tarp sveikatos priežiūros specialistų yra nepakankamas [17, 18]. 2015 m. Prancūzijoje atlikto tyrimo rezultatai atskleidžia, kad tik 26,3 proc. akušerių - ginekologų ar akušerių aptare burnos sveikatos klausimus su néščiosiomis. Ir tik 33,2 proc. specialistų sistemingai rekomenduoja pacientams apsilankyti pas odontologus [18]. Apibendrinant galima teigti, jog akušerines - ginekologines paslaugas teikiantys gydytojai turètų informuoti néščiąsias apie apsilankymo pas odontologą svarbą ir būtinumą ir taip prisideti prie burnos priežiūros skatinimo.

\section{Išvados}

1. Literatūroje daugèja straipsnių, nurodančių, kad prasta burnos būklè gali turèti įtakos nëštumo komplikacijoms išsivystyti, tačiau daugelis odontologų šios grèsmès neįvertina kritiškai ir mano, jog tarp minètų faktorių asociacijų nèra.

2. Sveikatos priežiūros specialistai prieštaringai vertina kai kurias odontologines procedūras nėštumo metu. Šio tyrimo duomenys patvirtina ir kitų tyrimų išvadas, jog trūksta moksliškai pagrịstos informacijos apie atliekamų procedūrų bei antibiotikų skyrimo saugumą.

3. Didžioji dalis néščiuju lankèsi pas odontologą ir mano, jog vizitai yra saugūs. Likusi dalis moterų nurodè, kad pagrindinè priežastis, dèl kurios joms nebuvo atlikta odontologinè apžiūra - buvo nusiskundimų neturèjimas.

4. Gydytojų rekomendacijos apsilankyti pas odontologus turi įtakos néščiųų apsisprendimui, tačiau mūsų atlikto tyrimo rezultatai rodo, kad mažiau nei pusè apklaustų akušerių pataria něščiosioms apsilankyti pas odontologus. Taip pat didžioji dalis apklaustų odontologų bei akušerių nebendradarbiauja tarpusavyje něšciujų burnos ertmès priežiūros klausimais. Todèl tarpprofesinès komunikacijos vystymas šiuo metu yra vienas iš svarbiausių uždavinių siekiant sumažinti moterų, likusių be odontologinès priežiūros, skaičių. 


\section{Literatūra}

1. Ide M, Papapanou NP. Epidemiology of association between maternal periodontal disease and adverse pregnancy outcomes - systematic review. J Periodontal 2013; 84(4):181-194. http://www.joponline.org/doi/pdf/10.1902/ jop.2013.134009 http://onlinelibrary.wiley.com/doi/10.1111/ cdoe.12057/epdf http://www.ijohsjournal.org/temp/IntJOralHealthSci4258-2171546_060155.pdf http://www.indianjournals.com/ijor.aspx?target $=$ ijor:ijcd $\&$ volume $=3 \&$ issue $=2 \&$ arti $\mathrm{cle}=002$

2. Laitala ML, Alanen P, Isokangas P, Soderling E, Pienihakkinen $\mathrm{K}$. Long-term effects of maternal prevention on children's dental decay and need for restorative treatment. Community Dentistry and Oral Epidemiology 2013; 41(6): 534-540.

https://doi.org/10.1111/cdoe.12057

3. Saldūnaitė K, BendoraitienėAE, Slabšinskienė E, Vasiliauskienė I, Andriuškevičienè V, Zūbienė J. The role of parental education and socioeconomic status in dental caries prevention among Lithuanian children. Medicina, (Kaunas) 2014; 50(3): 156-161. https://doi.org/10.1016/j.medici.2014.07.003

4. Reddy BS, Prakash S, Lakshminarayan N. Gynecologists' concerns about oral disease - A step to interdisciplinary approach. International Journal of Oral Health Sciences 2014; 4(2): 58-62. https://doi.org/10.4103/2231-6027.165100

5. Sampat SV, Hedge AM. Oral health status, knowledge and attitude of pregnant women towards oral hygiene in Mangalore. Indian Journal of Contemporary Dentistry 2015; 3(2): 6-9. https://doi.org/10.5958/2320-5962.2015.00031.5

6. The American College of Obstetricians and Gynecologists. Committee opinion no. 569. Oral health care during pregnancy and through the lifespan. 2013; 122: 417-422.

7. Achtari DM, Georgakopoulou AE, Afentoulides N. Dental care throughout pregnancy: what a dentist must know. 2012; 11(4):169-176.

8. Naidu GM, Ram KC, Kopuri RKC, Prasad SE, Prasad D, Babburi S. Is dental treatment safe in pregnancy? A dentist's opinion survey in South India 2013; 3(4): 233-239.

9. Lietuvos statistikos departamentas. Demografijos metraštis 2013. Vilnius, 2014; ISSN 2029-3739.

10. Pūrienė A, Grybienė R, Bond B, Žekonienė J, Pečiulienė V, Maneliené R. Accessibility of information about oral health and dental care to pregnant women in Vilnius 2011; 18(1): 23-29.

11. Vergnes JN, Pastor-Harper D, Constantin D, Bedos C, Kaminski M, Nabet C. et al. Perceived oral health and use of dental services during pregnancy: the MaterniDent study 2013; 25(3): 281-292.

12. Stafford EK, Shellhaas C, Hade ME. Provider and patient perceptions about dental care during pregnancy 2008; 21(1): 63-71.

13. Račienė R., Pečiulienė V., Bendinskaitė R. Moksleivių kreipimasis ị gydytoją odontologą profilaktinés apžiūros. Psichologiniai ir socialiniai veiksniai. Lietuvos bendrosios praktikos gydytojas, 2012 vasaris; 16(2).

14. Hemalatha V, Manigandan T, Sarumathi T, Aarthi Nisha V, Amudhan A. Dental considerations in pregnancy - a critical review on the oral care. Journal of Clinical and Diagnostic Research 2013; 7(5): 948-953. http://www.ncbi.nlm.nih.gov/ pmc/articles/PMC3681080/

15. Mendia J, Cuddy AM, Moore AP. Re-evaluating therapeutic drugs for your pregnant dental patients. 2013; 9(3): 58-70.

16. American academy of pediatric dentistry. Guideline on oral health care for the pregnant adolescent. 2012; 37(6): 159-165.

17. May L, Suminski R, Yeung YA, Linklater RL, Christensen C, Jahnke S. Pregnant patient knowledge and obstetric provider advice on oral health. 2014; 2(1): 6 .

18. Cohen L, Schaeffer M, Davideau J-L, Tenenbaum H, Huck O. Obstetric knowledge, attitude and behaviour concerning periodontal diseases and treatment needs in pregnancy: influencing factors in France. 2015; 86(3): 398-405.

19. George A, Dahlen H.G, Blinkhorn A, Ajwani S, Bhole S, Ellis S, Yeo A, Elcombe E, Sadozai A, Johnson M. Measuring oral health during pregnancy: sensitivity and specificity of a maternal oral screening (MOS) tool. BMC Pregnancy and Childbirth 2016; 16:347. DOI 10.1186/s12884-016-1140-4.

20. Riggs E, Yelland J, Shankumar R, Kilpatrick N. 'We are all scared for the baby': promoting access to dental services for refugee background women during pregnancy. BMC Pregnancy and Childbirth 2016; 16:12. DOI 10.1186/s12884-015-0787-6.

\section{ASSESSMENT ON DENTISTS, MIDWIVES AND PREGNANT WOMEN PERCEPTION AND KNOWLEDGE OF ORAL DISEASES, TREATMENTS AND PROPHYLAXIS DURING PREGNANCY IN KAUNAS}

E. A. Bendoraitienè, A. Marcinkevičiūtė, M. Gutpetris

Key words: pregnancy, oral health, prenatal care.

Summary

Aim: to evaluate and compare provider and pregnant women knowledge and attitudes towards oral prophylaxis and treatment of diseases, their necessity, accessibility and safety during pregnancy. Methods. Anonymous survey conducted at public medical institutions in Kaunas. The study involved 41 dentist, 53 midwives and 341 pregnant women. Results. Most of the midwives believe that poor oral health can lead to adverse pregnancy outcomes compared with dentists. Dentists poorly acknowledged pregnant women's knowledge and understanding of the importance of dental care compared with midwives ( $\mathrm{p}<0,05$ ). 68,3\% expecting women visits the dentist. $88 \%$ of women indicated that visits are safe. $83 \%$ of dentists and $75,5 \%$ of midwives don't cooperate with each other. $79,8 \%$ of pregnant women visit the dentist as they were recommended by the doctor $(\mathrm{p}<0,001)$. Conclusion. During pregnancy, there is a higher risk of developing oral pathology, which can determine pregnancy outcome. Most of the pregnant women visit their dentist and believes that visits are safe. A doctor's recommendation to visit a dentist has an impact on decision for pregnant women.

Correspondence to: egbe68@yahoo.co.uk

Gauta 2016-11-16 